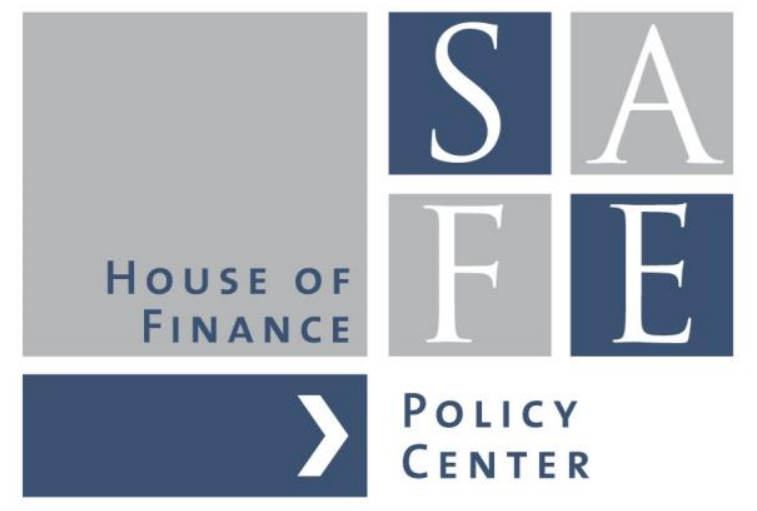

Otmar Issing

\title{
Central Banks - from Overburdening to Decline?
}

White Paper No. 42

SAFE I Sustainable Architecture for Finance in Europe A cooperation of the Center for Financial Studies and Goethe University Frankfurt 
SAFE Policy papers represent the authors' personal opinions and do not necessarily reflect the views of the Research Center SAFE or its staff. 


\section{Central Banks - from Overburdening to Decline?}

Otmar Issing

4 October 2016

\section{The fundament of credibility}

Over decades if not centuries the reputation of central banks has been rather volatile. As a global phenomenon it reached a peak before and around the turn of the century. The Bundesbank has been exceptional as this institution had developed its high prestige already at a much earlier stage. As "guardian" of the DM the Bundesbank (and its predecessor the "Bank deutscher Länder") has delivered a stable currency to the German people who had lost their (nominal) wealth twice in one generation. The almost "pathological" relation of Germans with their currency (as I once called it) was demonstrated again when the countrymen in the East announced to come to the DM if the DM would not come to them. What is interesting in this context is the fact that other central bankers and even academics who were very critical of the Bundesbank's monetary policy and its "monetarist approach" showed great respect for this institution and its representatives.

It would be interesting to explore further the underlying reason for this phenomenon. What creates credibility? Is it just a track record irrespective of the underlying policy approach, the theoretical underpinning?

On the global level in retrospect the personality of Alan Greenspan is a prominent example for "personalities matter" and to me also represents a kind of enigma. He managed to fascinate people by giving speeches on monetary policy in which you would hardly find the word "money" or even other nominal variables. It was a time when transparency and communication became fundamental for the reputation of a central bank (Issing, 2005). What is surprising is the fact that according to the media and even academia the communication by the chairman of the Fed was acknowledged as a kind of a benchmark for transparency. To quote just one example of this puzzle, Bob Woodward (2000) in his book "Maestro" wrote: "Greenspan's policy of expanding openness and transparency has done more than merely increase the Fed's accountability..." (p. 226). But, only one page later he claims: "Greenspan can subtly confound his audience. (...) He does not provide a clear declaration about the condition of the economy or the likely direction of interest rates. His long, convoluted sentences seem to take away in the end what they have given at the beginning, as they flow to new levels of incomprehensibility. He uses what he calls 'constructive ambiguity' ". 
The ECB as the youngest central bank in the world was the first to hold a press conference after every monetary policy meeting where the President was ready to answer questions from a crowd of journalists - a practice that has later been emulated around the globe. Nevertheless we were seen as the embodiment of in-transparency. W. Buiter (1999) conferred on me the dubious title of the "enforcer for the ECB Opaqueness Squad". But, this personal recollecting is irrelevant. What is, however, of general interest is the aura which surrounded Greenspan and can still be observed although to a lesser degree in other cases. Karl Brunner (1981) once criticized a sort of "metaphysical approach" to monetary policy. To some extent this special prestige might support credibility. On the other hand, one can observe that this kind of privilege can in the course of time be also a cause for a rather deep collapse in the reputation of a central banker.

One might call this "Personality Overburdening" i.e. too high expectations placed on a leading central banker, expectations which in the end might lead to great disappointments. Personal reputation is also exposed to volatility. Neither the initial phase nor the following decline must be the responsibility of a special person although it might be difficult to withstand the temptation of tolerating if not fostering the emergence of this aura.

\section{Institutional Overburdening}

"Institutional Overburdening" to a large extent was a consequence of the "Great Moderation". This term indicates that it was a period in which inflation had come down from rather high levels. Growth and employment were at least satisfying and variability of output had substantially declined. Was this "goldilock economy" the result of just luck due to a decline in exogenous shocks (Stock and Watson, 2003) or of improved macro policies, especially monetary policy (Romer and Romer, 2002)? The jury on this question is still out. But this period has substantially increased the reputation of central banks and central bankers. It was almost unavoidable that as a consequence expectations on future actions of central banks and their ability to control the economy reached an unprecedented peak which was hardly sustainable.

The latest Annual Report of the BIS (p. 22) presents a concise assessment: "And yet the extraordinary burden placed on central banking since the crisis is generating growing strains. During the Great Moderation, markets and the public at large came to see central banks as all-powerful. Post-crisis, they have come to expect the central bank to manage the economy, restore full employment, ensure strong growth, preserve price stability and foolproof the financial system. But in fact, this is a tall order on which the central bank alone cannot deliver. The extraordinary measures taken to stimulate the global economy have sometimes tested the boundaries of the institution. As a consequence, risks to its reputation, perceived legitimacy and independence have been rising." 
Disappointments with "politics" in general and loss of trust in politicians contributed to concentrating expectations on the competence of central banks. The crisis of EMU is a special case which is characterized by the ECB seen as the "only game in town". We will later come back to this phenomenon.

Institutional overburdening has two dimensions. One is coming from exaggerated expectations on what central banks can achieve ("expectational overburdening") - as explained by the BIS.

The other dimension is "operational overburdening" i.e. overloading the central bank with more and more responsibilities and competences. The biggest challenge is implied in the responsibility for financial stability. The financial crisis triggered an intensive discussion to what extent central banks should be made directly responsible for financial stability and how they should act to deliver on this goal. A consensus has emerged that preserving price stability is not enough. As the phase of the great moderation has demonstrated huge risks to the stability of the financial sector can develop while low inflation is preserved. Following Minsky, a stable environment might even foster the build-up of financial fragility which will end in a collapse of the whole system.

Is there a trade-off between price stability and financial stability? This is the key question arising from the above consensus. While a short-term conflict cannot be excluded there is no reason to sacrifice price stability over the medium to long-term with the aim of fostering financial stability (Issing, 2003). However, a central bank loses its reputation if it is perceived as having underestimated or even neglected the challenge of financial instability. This is basically true almost independently of whether the central bank has an official/legal mandate in this field or not.

Would it not be appropriate to include explicitly financial stability as a goal in the mandate of the central bank (see e.g. Smets, 2014)? Before coming back to this problem one should ask what traditional monetary policy can achieve to preserve or at least foster financial stability. One observation is obvious: the inflation targeting approach is unable to meet this challenge. In contrast, the ECB's two-pillar monetary strategy explicitly considers developments in the field of money and credit when taking monetary policy decisions (Issing, 2011). What is implicit in this approach is the leaning against the wind, by the way in both directions i.e. against the risk of boom and bust.

There is no place here to enter a long and still ongoing discussion what the strategy of leaning against the wind can achieve. But, one conclusion seems clear. A monetary policy of simply ignoring money and credit i.e. a pure inflation targeting approach has been discredited by the financial crisis. The fact that this message is widely ignored is evidence that conceding mistakes is not an outstanding characteristic neither in central banks nor in wide circles of academia. 
Ignoring critique is always a misleading attitude. In the context of the great financial crisis an encompassing analysis of past policies is badly needed and neglecting critique is extremely dangerous. In a number of studies the BIS has warned against the repetition of mistakes in the past. Taylor and Wieland (2016) demonstrate evidence that the policy of the Fed contributed to the overheating of the economy. Does the continuation of the policy of extremely low interest rates combined with additional expansionary measures not imply the risk of creating again a situation which turns out to be unsustainable and ending in a collapse of financial markets? And does the expectation that central banks and governments will again have to play the role of saviors of the system not create moral hazard - remember the "Greenspan put"?

If one considers the communication of the Fed and its policy such thoughts are put aside. It seems that the dominating view, probably on a global level is still in line with the message presented by Alan Blinder (2005) not long before the collapse of financial markets in the great financial crisis: "The 'mop up after strategy' received a severe real world stress test in 2000-02, when the biggest bubble in history" (sic!) imploded, vaporizing some USD 8 trillion in wealth in the process. It is noteworthy, but insufficiently noted, that the ensuing recession was tiny and not a single sizable bank failed. In fact, and even more amazing, not a single sizable brokerage or investment bank failed either. Thus, the fears that the 'mop up after strategy ' might be overwhelmed by the speed and magnitude of the bursting of a giant bubble proved to be unfounded. Regarding Greenspan`s legacy, then, we pose a simple rhetorical question. If the mopping-up strategy worked this well after the mega-bubble burst in 2000 , shouldn't we assume that it will also work well after other, presumably smaller, bubbles burst in the future? Our suggested answer is apparent."

Unfortunately, this strategy of letting bubbles emerge and to come in with "mopping-up after" has produced or at least contributed to a much more disastrous financial crisis. It is extremely alarming that such thinking might be behind present monetary policies.

For a while, macroprudential policy was seen as a kind of panacea to avoid potential conflicts between monetary policy aimed at preserving price stability and financial stability. In the meantime a more skeptical view is dominating. Experience with these new instruments is lacking and implementation of these tools raises many more questions than was imagined.

The assignment of macroprudential competence to the central bank or outside can be seen differently (see e.g. Bundesbank, 2015). If the central bank has a direct legal responsibility for financial stability, it should dispose of all necessary instruments. There is an ongoing discussion whether financial stability should be a legal mandate for the central bank. Efficiency aspects seem to argue in favor of bringing responsibility and competence into one institution, the central bank. However, high risks for the reputation of the central bank and its credibility constitute strong 
arguments against such an assignment. And the other side of overburdening the central bank is the concern that central banks might become too powerful to retain the status of independence from politics.

\section{The ECB - a special case}

So far one might recognize an overburdening which applies more or less to all major central banks. The ECB is unique in the sense that it is the central bank of - in the meantime - 19 states. This arrangement brings the ECB in a special position which implies a kind of "extra institutional overburdening" which goes beyond the challenges identified above.

The establishment of the Single Supervisory Mechanism extended the mandate of the ECB and made it even more important than before. However, being now also responsible for banking supervision implies a substantial reputational risk. Will the ECB always timely identify problems in individual banks? Will it communicate its assessment in a way which will avoid conflicts with other political authorities? Will the financial markets and finally also the general public be content with this enlarged role of the central bank? In its 2009 report the High-Level Group on Financial Supervision in the EU (de Larosière et al.) presented three arguments against giving this competence to the ECB:

- $\quad$ Potential conflicts with monetary policy;

- $\quad$ Greater risk of political pressure;

- $\quad$ Possible interference with the ECB's independence in cases where tax payers' money has to be invested to provide financial support for banks.

As a consequence the Group suggested that the EU should take steps leading to the creation of an independent European Supervisory Authority. This proposal was initially approved by the Council and the Commission. In the end a change in the Treaty would have been necessary to establish such an authority. For the foreseeable future there is no chance for this. Notwithstanding doubts on the legal basis for this decision the ECB was given this competence.

In the very short period of its existence conflicts between banking supervision and monetary policy have already become visible. There is the risk of a negative feedback from this arrangement on the behavior of financial intermediaries. These might be encouraged to take higher risks because they know that the supervisor does not want to lose reputation and has the means to protect banks from running into dangerous troubles. This risk of moral hazard applies in first place to financial institutions too big or too interconnected to fail. (One might call it a micro Greenspan put.) In this respect the ECB is in the same position as many other central banks. However, the ECB seems to be more than content with its enhanced authority. This is evidenced by the fact that in a recent report by the five presidents - the president of the ECB being one of them - the new institutional 
arrangement on banking supervision was not even mentioned among a number of forward-looking proposals which would imply a change of the Treaty.

An unprecedented degree of overburdening for the central bank has unfolded in the course of the crisis of EMU. This became obvious in May 2010 when the ECB embarked in a political responsibility by buying government bonds of countries that otherwise would have experienced substantial increases in long term interest rates. No doubt this was a lose-lose situation for the central bank because it was confronted with the risk that without this intervention financial markets might have been exposed to turmoil for which the ECB would have been made responsible. This, however, does not hide the fact that the central bank acted because politics, fiscal policies of member states, were not able to meet their obligations. In spite of the fact that the ESM was established, the action of the ECB was widely interpreted as a kind of a guarantee for the membership of every country in the $E M U$, and what is most important, a guarantee for the existence of the euro itself. This notion was driven to the extreme by the famous "whatever it takes" announcement. Further monetary policy decisions of the ECB from which problem countries and banks profited mostly supported this view. The decisions by the European Court of Justice and the German Constitutional Court all in all have rejected the accusation that the ECB exceeded its mandate and violated the Treaty.

It is difficult to understand the economic logic behind the legal argumentation. Mervyn King (2016b), a prominent former central banker who is widely respected for his concise and well-funded observations recently came out with this clear statement: "The proposal for outright monetary transactions is a transfer from countries that can borrow cheaply to countries that can't borrow cheaply. There's no point dressing it up with fancy language such as measures to improve the transmission mechanism of monetary policy. It's a straight transfer from countries that have credibility in their ability to run their public finances to countries that don't. From that perspective, it clearly violates the no-bailout clause of the European Treaty, and it runs completely counter to this vision of the monetary union."

But the fact alone that measures taken by the central bank led to cases before the court is anything but supportive for the reputation of the central bank. There is a high risk that future actions of the ECB might lead to new litigations.

It is not surprising that in the context of these legal combats new discussions on the status of the ECB emerged. In Maastricht the ECB was endowed with independence from politics "when exercising the powers and carrying out the tasks and duties conferred upon them by this Treaty and this statute". The court cases concentrated on the question whether the ECB has acted within its mandate or went beyond. Uncertainty on this fundamental question necessarily leads to critic of the statute. Beyond the legal interpretation of the existing mandate a long-standing dissent came again to the fore. 
Independence was given to the ECB by a unanimous decision of member states, yet not everywhere with the same conviction. In the run-up to the French referendum e.g. President Mitterrand in a televised debate emphasized that the technocrats at the future central bank would not decide exercising their own competence but implement the decision taken by the Council (see Issing, 2008 p. 59). This was an extreme comment totally out of line with the just approved legal situation. But doubts about the appropriateness of the status of the ECB never disappeared. This is not surprising as mandating "unelected technocrats" with independence from politics in such an important field evidently raises questions on the democratic legitimacy of such an arrangement. There exists a vast literature on this important subject. Nevertheless, what matters in the present situation are two aspects. Firstly, a central bank which is seen as to transgress the limits of its mandate causes resistance and beyond litigations stirs initiatives against the status of independence. Secondly, objections against independence grow more than proportionally with the extension of the mandate. Given more power to the central bank not only overburdens the institution but at the same time undermines the case and support for its independence.

The more politics of member states fail to fulfill their responsibility the more the ECB is seen as the only institution within EMU which has the power and ability to act and disposes of the necessary instruments what in this context boils down to providing credit at low interest rates and buying government bonds to prevent the emergence of larger spreads in long-term interest rates. These actions undermine and even destroy the working of financial markets as guardians of sound fiscal (and other) policies. As a consequence member states can delay or even dismiss badly needed reforms without the risk of losing credibility in the financial markets. The implicit as well as explicit strategy of the ECB has been to take additional expansionary monetary policy measures to compensate for missing structural reforms (Coeure 2016). The ECB reacts to this critique by emphasizing that it has no mandate to "punish" member states for a lack of structural reforms. But, has the ECB a mandate to suppress market reactions which would signal lack of confidence in national politics? Under these circumstances how credible is the strong request for structural reforms in every Introductory Statement by the president repeated in testimonies to the European Parliament and in numerous speeches?

Being seen as the only game in town demonstrates an existential disequilibrium in the distribution of political power in the EMU. It signals an extreme case of overburdening of the central bank in almost every respect - creating expectations, assigning a political role for which a central bank has not and must not have a mandate. One might concede that the ECB did not seek this role. But so far, there is hardly any signal from the central bank that it will start to reduce and finally stop its politically motivated interventions. Rather the opposite can be observed when the ECB is progressing on this 
slippery road. Whereas the ECB is heavily engaged in expansionary monetary policy with the political aim to guarantee the cohesion of EMU it is confronted with the de facto destruction of the Stability and Growth Pact. This is highly deplorable as the Pact was seen as the fiscal counterpart to monetary stability. EMU was built on the idea of the two pillars of monetary stability and fiscal solidity.

The extension of its tasks and the increasing political role will and has already triggered a debate on the legitimacy of such power given to an independent central bank in a democratic society. The irony lies in the fact that no matter whether the ECB's actions in the longer run are proven successful or not, the status of independence will be at stake anyway.

\section{Concluding remarks}

People in ancient Greece tried to hide a personal lucky situation being afraid that the gods might become envious and punish human haughtiness. These times of superstition are behind us. But, is it not almost a kind of general law that after a rise follows a decline? In this sense, shouldn't the alarm bell have ringed for the central banks when their prestige in public reached a peak? No reason to fear interventions by envious gods but this time of glory could have constituted an especially suitable time to show a degree of humility.

This attitude is, however, appropriate in principle all the time. Imperfect knowledge is a pertinent feature for the conduct of monetary policy. Models as a basis for monetary policy are exposed to a high degree of uncertainty. The complexity and elegance of a new generation of models might increase the danger to underestimate the great dimension of uncertainty. Our understanding of the dynamics of prices and economic activity and the transmission mechanism of monetary policy measures is still limited. In the context of the evolution of highly complex and globally interconnected financial markets uncertainty has anything but declined.

Following Woodford (2005) very little else than expectations about monetary policy matter. Even if one does not go so far central banks focus on controlling or - more cautiously spoken - on guiding expectations. Accordingly, communication has entered the center stage. With central bank interest rates more or less at the zero bound, guiding expectations has become even more important and at the same time more difficult. Central banks reacted to this challenge by introducing forward guidance. The enthusiasm about this "revolution" (Yellen, 2012) after a few years has substantially abated. A sequence of different approaches adopted by the Fed demonstrates that forward guidance did not meet the high expectations attributed to this new instrument of communication. Sound analysis alone should have sufficed to understand that it could not have done so (Issing, 2014). The intention of forward guidance is to reduce the uncertainty of the public about future monetary policy. However, there is no way to overcome the uncertainty to which the central bank itself is 
exposed. Giving a different impression via forward guidance the central bank delivers a new example of pretence of knowledge.

Central bank interest rates at or close to the zero bound - more recently supported by forward guidance- have now existed for many years. The longer this situation continues the more central banks are confronted with a dilemma. Once they consider to raise interest rates to contain inflationary developments they risk to undermine the stability of the financial sector which has substantial low fixed interest assets in its portfolio. Even small increases in interest rates would create huge losses. One might ask if central banks are already trapped in "financial dominance".

In his remarkable book "The End of Alchemy" Mervyn King (2016a) reminded us of the difference between risk and uncertainty (which goes back to F. Knight). "In a world of radical uncertainty there is no way of identifying the probability of future events and no set of equations that describes people's attempt to cope with, rather than optimize against, that uncertainty. A common saying among economists is that 'it takes a model to beat a model'. But this overlooks the fact that whereas a world of risk can be described by equations representing optimizing behavior, a world of radical uncertainty cannot be so described" (p. 304).

There is no answer to this challenge, yet. But central banks must deal with risk and uncertainty in a way which does not confuse the public and at the same time does not lead into the trap of pretence of knowledge. Again, a sign of humility might be the best protection against the threat of hurting people's trust.

The status of independence of central banks is increasingly undermined by two developments. One is coming from instruments with distributional consequences like cheap credit to special groups, banks or companies. It is true that any monetary policy decision unavoidably will also have distributional consequences. These are normal side effects whereas the instruments mentioned have direct, planned discriminatory effects. Decisions of this kind must remain in the domain of politics which finally are controlled by voters and cannot be the competence of an independent central bank.

The other conflict with the status of independence is implied in acts of coordination with fiscal policy. The more monetary policy measures are de facto an act of fiscal policy - see the case of the ECB the more it is exposed to criticism that this is not compliant with the status of independence. To the extent that the central bank yields to political pressure, independence might still exist "de jure", but it has been abandoned "de facto". Fiscal dominance is the consequence of this.

A wide consensus has emerged that monetary policy at the zero bound having applied a lot of unconventional measures has come to a limit and negative side effects might already dominate. With high public debt restricting the room for expansionary fiscal policy "helicopter money" is now seen as 
the solution. In the meantime all kinds of variations have been discussed. Adair Turner (2016) in his book "Between Debt and the Devil" has presented a concise concept. The main idea is that the central bank brings money into circulation not via the banking sector as it used to do but by transferring money to the finance ministry. The status of independence should guarantee that the central bank always controls the respective amount of money creation.

Can one really expect that a central bank which once has embarked on such a role will be able to say "No" in future cases? Political and public pressure will be strong and always find socially important tasks which need to be financed by the central bank. And what about appointing central bankers which have an "open mind" and understanding for urgent political priorities?

De jure independence or lack of it will not matter anymore in such a regime - the decline of central banks will be completed and will end in inflation (which will later lead to new discussions on the best statute for a central bank). 


\section{References}

Bank for International Settlements (2016), 86th Annual Report, Basel 26th June.

Blinder, A.S., and Reis, R. (2005), Economic Performance in the Greenspan Era: The Evolution of Events and Ideas, in: The Greenspan Era: Lessons for the Future, Federal Reserve Bank of Kansas City, ed.

Brunner, K. (1981), The Art of Central Banking, in K. Brunner (1981) "The art of central banking", in H. Göppl and R. Henn (eds), Geld, Banken und Versicherungen, vol. 1 (Königstein).

Buiter, W.H. (1999), "Alice in Euroland”, Journal of Common Market Studies, No. 2.

Bundesbank (2015), Die Bedeutung der makroprudenziellen Politik für die Geldpolitik, Monatsbericht März.

Coeure, B. (2016), The ECB`s operational framework in post-crisis times, Speech in Jackson Hole on 27 August.

de Larosière, J., Balcerowicz, L., Issing, O. Masera, R., Mc Carthy, C., Nyberg, L., Pérez, J., and Ruding O., (2009), 'The High-Level Group on Financial Supervision in the EU', Report, Brussels, February

Issing, O. (2003), Monetary and financial stability: Is there a trade-off?, BIS, Monetary stability, financial stability and the business cycle: five views, Basel, September.

Issing, O. (2005), Communication, Transparency Accountability. Monetary Policy in the Twenty-first century, Federal Reserve Bank of St. Louis, Review, March/April.

Issing, O. (2008), The Birth of the Euro, Cambridge.

Issing, O. (2011), Lessons for monetary policy: What should the consensus be?, IMF Working Paper, April.

Issing, O. (2014), Forward Guidance: A new Challenge for Central Banks, SAFE Policy Center, White Paper Series No. 16, Frankfurt

King, M. A. (2016a), The End of Alchemy: Money, Banking, and the Future of the Global Economy. WW Norton \& Company.

King, M. A. (2016b), Interview, Quarterly Journal of Central Banking, August.

Masciandaro, D. (2016), Monetary Policy and banking supervision: still at arm's length? A comparative analysis. The European Journal of Comparative Economics, Vol. 9, n.3

Romer. C.D. and Romer, D.H. (2002), The Evolution of Economic Understanding and Postwar Stabilization Policy, NBER Working Paper 9274, October.

Smets, F. (2014), Financial stability and monetary policy: How closely interlinked?, International Journal of Central Banking, 10.

Stock, J.H. and Watson, M.W. (2003), Understanding Changes in International Business Dynamics, NBER Working Paper 9859, July.

Taylor, J.B. and Wieland, V. (2016), Finding the Real Equilibrium Interest Rate in a Fog of Policy Deviations, CEPR Discussion Paper Series No. 11264.

Turner, A. (2015). Between debt and the devil: money, credit, and fixing global finance. Princeton University Press. 
Woodford, M. (2005). Central bank communication and policy effectiveness (No. w11898). National Bureau of Economic Research.

Woodward, B. (2000), Maestro, New York.

Yellen, J. L. (2012). Revolution and Evolution in Central Bank Communication, November 13. 